\title{
Soninke Language
}

National Cancer Institute

\section{Source}

National Cancer Institute. Soninke Language. NCI Thesaurus. Code C154126.

A Niger-Congo Mande language spoken by the Soninke people of Africa. 